Career Trends and Characteristics of Former DOE Postdoctoral Appointees

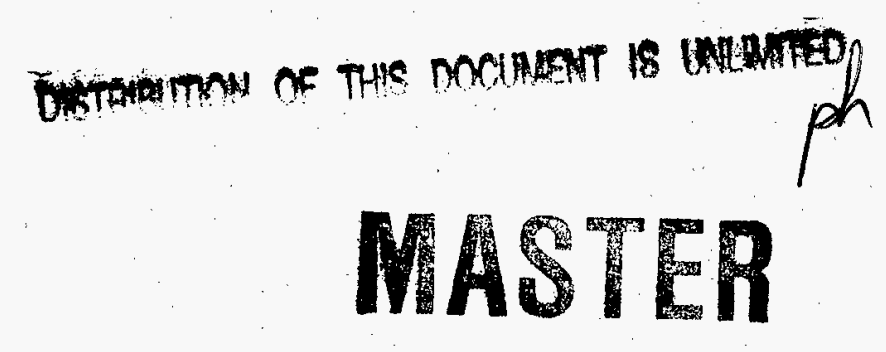

October 1996

Prepared by:

Analysis and Evaluation Programs

Education and Training Division

Oak Ridge Institute for Science and Education

Prepared for:

Office of Energy Research

U.S. Department of Energy 
The Oak Ridge Institute for Science and Education (ORISE) was established by the U.S. Department of Energy to undertake national and international programs in education, training, health, and the environment. ORISE and its programs are operated by Oak Ridge Associated Universities (ORAU) through a management and operating contract with the U.S. Department of Energy. Established in 1946, ORAU is a consortium of 89 colleges and universities. 


\section{DISCLAIMER}

This report was prepared as an account of work sponsored by an agency of the United States Government. Neither the United States Government nor any agency thereof, nor any of their employees, makes any warranty, express or implied, or assumes any legal liability or responsibility for the accuracy, completeness, or usefulness of any information, apparatus, product, or process disclosed, or represents that its use would not infringe privately owned rights. Reference herein to any specific commercial product, process, or service by trade name, trademark, manufacturer, or otherwise does not necessarily constitute or imply its endorsement, recommendation, or favoring by the United States Government or any agency thereof. The views and opinions of authors expressed herein do not necessarily state or reflect those of the United States Government or any agency thereof. 


\title{
Career Trends and Characteristics of Former DOE Postdoctoral Appointees
}

\author{
Prepared by: \\ Michael G. Finn \\ Analysis and Evaluation Programs \\ Education and Training Division \\ Oak Ridge Institute for Science and Education
}

Prepared for:

Office of Energy Research

U.S. Department of Energy

October 1996

This report is based on work performed under Contract No. DE-AC05-760R00033 between the U.S. Department of Energy and Oak Ridge Associated Universities.

All opinions expressed in this paper are the authors' and do not necessarily reflect policies and views of the U.S. Department of Energy or Oak Ridge Associated Universities. 


\section{Table of Contents}

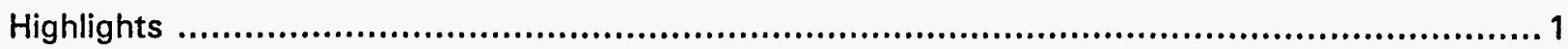

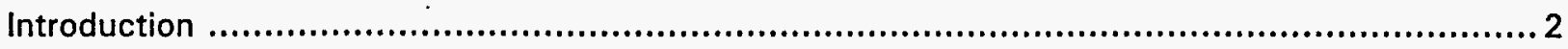

Demographic Characteristics ...................................................................... 2

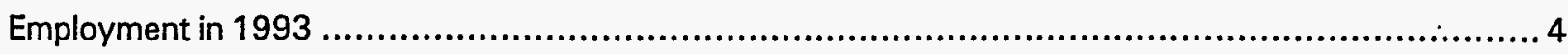

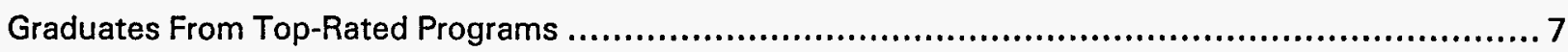

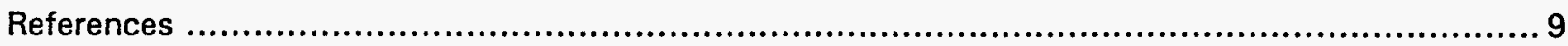

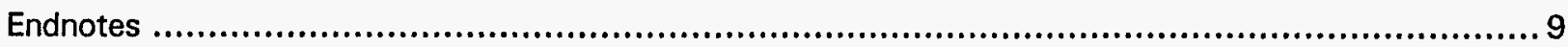

\section{List of Figures}

Figure 1. Percent of Former Physical Science Postdoctorates Graduating from Top-Rated Programs ... 8

\section{List of Tables}

Table 1. Gender of Former Science and Engineering Postdoctorates,

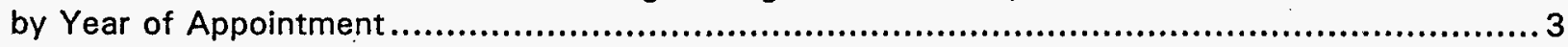

Table 2. Race/Ethnicity of Former Science and Engineering Postdoctorates,

by Year of Appointment ................................................................................. 3

Table 3. Place of Birth of Former Science and Engineering Postdoctorates,

by Year of Appointment ............................................................................... 4

Table 4. Field of Study of Former Science and Engineering Postdoctorates,

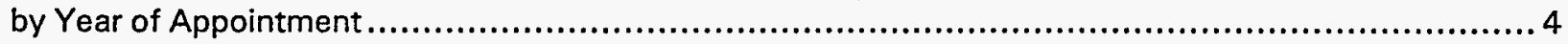

Table 5. Percent of Former Science and Engineering Postdoctorates

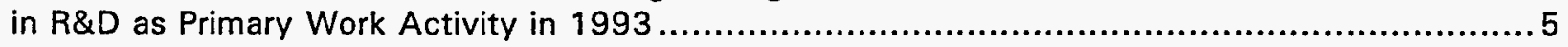

Table 6. Percent of Former Science and Engineering Postdoctorates

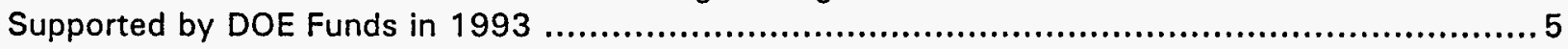

Table 7. 1993 Employer of Former Science and Engineering Postdoctorates,

by Year of Appointment ................................................................................ 6

Table 8. 1993 Work Activities of Former Science and

Engineering Postdoctorates .............................................................................. 7 


\section{HIGHLIGHTS}

Among former DOE-funded postdoctorates who were employed in the United States in 1993:

- The degree fields of DOE-funded postdocs have been mostly in the physical sciences, followed by life sciences, and engineering.

- Nearly one-half were engaged in work supported by the DOE in 1993 . The former DOE postdocs were more than ten times as likely to be engaged in DOE-supported work as were other postdocs from the same period but who did not have DOE-supported postdoctoral appointments.

- Nearly 80 percent reported that R\&D work constituted their primary work activity in 1993.

- Energy, environment, and health/safety issues were the main focus of about a quarter of these doctorates in 1993. Basic research was the focus of most of the rest.

- Compared with other postdocs from the same years, former DOE postdocs were about as likely to work at a 4-year college or university, less likely to work at a medical school, but more likely to work at a DOE M\&O facility or a university research institute.

- Most DOE postdocs in the physical sciences graduated from top-rated graduate programs. This is more frequently true for DOE-funded postdocs than for other postdocs in the physical sciences. 


\section{INTRODUCTION}

This report presents data on doctorates with degrees from U.S. universities who held DOEfunded postdoctoral appointments during the period from 1973 to 1993 . The report uses data from the Survey of Doctorate Recipients, a longitudinal survey which has been conducted during odd-numbered years since 1973. Persons with a science or engineering doctorate who reported their job as a postdoctoral appointment in one or more of these years is counted as a DOEpostdoc if they also reported that their work was supported by the Department of Energy or its predecessor agencies at the time of the postdoctoral appointment.

The report provides statistics describing the status of these former DOE-postdocs and a comparison group of other postdocs in 1993. The number of former DOE postdocs employed in the United States in 1993 was 1,440. While the estimates in this report are based on a large and representative national sample, the total of 1,440 former postdocs represented is certainly smaller than the total of all former postdocs, e.g., because the survey excludes persons with foreign doctorates and persons who resided outside the United State in 1993.'

An examination of the time period during which these doctorates first reported a postdoctoral appointment to the biennial Survey of Doctorate Recipients indicates a trend toward an increasing number of DOE-funded postdocs. Among those employed in 1993, an average of only about 90 per year reported DOE-funded postdoctoral appointments during the 1973 to 1983 period. This increased to about 160 annually during 1985 to 1987 , and to about 290 annually from 1989 to 1991 .

In the tables that follow, data are presented for all the doctorates reporting postdocs over the period examined. For purposes of comparison, data are also presented for the doctorates whose postdoctoral appointment was made in 1989 or later. Sample size restrictions prevent presenting data for each of several time periods, but the contrast of the most recent period with the total does give some sense of changes that may be occurring. The first section below refers to demographic characteristics of former postdocs. It includes all who reported a postdoc between 1973 and 1993. Subsequent sections focusing on the 1993 employment of former postdocs include postdocs between 1973 and 1991.

\section{Demographic Characteristics}

Only 13 percent of former DOE postdocs for the period 1973-1993 were female. However, the percent female postdocs appears to be increasing; it was 15 percent for persons reporting a DOE postdoc in 1989 to 1993 . Non-DOE postdocs were much more likely to be females. (See Table 1.) 
Table 1. Gender of Former Science and Engineering Postdoctorates, by Year of Appointment

\begin{tabular}{|c|c|c|c|c|}
\hline \multirow[b]{2}{*}{ Gender } & \multicolumn{2}{|c|}{$1989-1993$} & \multicolumn{2}{|c|}{$1973-1993$} \\
\hline & $\begin{array}{c}\text { DOE } \\
\text { Postdocs }\end{array}$ & $\begin{array}{l}\text { Non-DOE } \\
\text { Postdocs }\end{array}$ & $\begin{array}{c}\text { DOE } \\
\text { Postdocs } \\
\end{array}$ & $\begin{array}{l}\text { Non-DOE } \\
\text { Postdocs }\end{array}$ \\
\hline $\begin{array}{l}\text { Female } \\
\text { Male }\end{array}$ & $\begin{array}{l}15 \% \\
85\end{array}$ & $\begin{array}{l}31 \% \\
69\end{array}$ & $\begin{array}{l}13 \% \\
87\end{array}$ & $\begin{array}{l}29 \% \\
71\end{array}$ \\
\hline TOTAL & $100 \%$ & $100 \%$ & $100 \%$ & $100 \%$ \\
\hline
\end{tabular}

Only 3 percent of former DOE postdocs are members of underrepresented minority groups (African-Americans, Hispanic-Americans, or Native Americans). In this regard, DOE postdocs are similar to non-DOE postdocs and to the larger population of all doctoral scientists and engineers. (See Table 2.)

Table 2. Race/Ethnicity of Former Science and Engineering Postdoctorates, by Year of Appointment

\begin{tabular}{lccccc} 
& \multicolumn{2}{c}{$1989-1993$} & & \multicolumn{2}{c}{$1973-1993$} \\
\cline { 3 - 3 } Race/Ethnicity & $\begin{array}{c}\text { DOE } \\
\text { Postdocs }\end{array}$ & $\begin{array}{c}\text { Non-DOE } \\
\text { Postdocs }\end{array}$ & & $\begin{array}{c}\text { DOE } \\
\text { Postdocs }\end{array}$ & $\begin{array}{c}\text { Non-DOE } \\
\text { Postdocs }\end{array}$ \\
\hline Underrepresented Minorities & $2 \%$ & $5 \%$ & & $3 \%$ & $4 \%$ \\
Asian Americans & 27 & 25 & & 21 & 17 \\
White Non-Hispanics & 71 & 70 & & 76 & 79 \\
TOTAL & $100 \%$ & $100 \%$ & & $100 \%$ & $100 \%$
\end{tabular}

Only 69 percent of the former DOE postdocs in this study were born in the U.S. ${ }^{2}$ However, some of the foreign-born DOE postdocs had become U.S. citizens by 1993 . The percent foreign-born is higher among the DOE postdocs than among other postdocs. For both DOEfunded and other postdocs, the participation of foreign-born was highest in the most recent cohorts, those reporting postdocs in 1989 to 1993. (See Table 3.) 
Table 3. Place of Birth of Former Science and Engineering Postdoctorates, by Year of Appointment

\begin{tabular}{lccccc} 
& \multicolumn{2}{c}{$1989-1993$} & & \multicolumn{2}{c}{$1973-1993$} \\
\cline { 2 - 3 } Place of Birth & $\begin{array}{c}\text { DOE } \\
\text { Postdocs }\end{array}$ & $\begin{array}{c}\text { Non-DOE } \\
\text { Postdocs }\end{array}$ & & $\begin{array}{c}\text { DOE } \\
\text { Postdocs }\end{array}$ & $\begin{array}{c}\text { Non-DOE } \\
\text { Postdocs }\end{array}$ \\
\hline $\begin{array}{l}\text { U.S. Born } \\
\text { Foreign Born: }\end{array}$ & $65 \%$ & $67 \%$ & & $69 \%$ & $76 \%$ \\
$\quad$ Naturalized U.S. Citizen in 1993 & 5 & & & & \\
$\quad$ Not a U.S. Citizen in 1993 & 30 & 27 & & 23 & 7 \\
TOTAL & $100 \%$ & $100 \%$ & & $100 \%$ & $100 \%$
\end{tabular}

The demographic characteristics described above largely reflect the degree field distribution. of former DOE postdocs. DOE postdocs come disproportionately from the physical sciences. Compared with the life sciences, the physical science doctorate recipients in recent years have been somewhat less likely to be U.S. citizens or underrepresented minorities and much less likely to be females. (NSF, 1993.)

\section{Employment in 1993}

Virtually all of the former postdocs from the 1973 to 1991 period were employed in 1993. Table 4 shows the fields of doctoral study for these former postdocs. The physical sciences are the degree programs where most DOE postdocs received their doctoral degrees, and the life sciences are a distant second. For non-DOE funded postdocs, the degree field origins are just the opposite; life science degrees greatly outnumber physical science degrees. Engineering and mathematics/computer science graduates typically make up a relatively small proportion of postdocs, but the DOE-funded postdocs are more likely to come from these fields than are other postdocs.

Table 4. Field of Study of Former Science and Engineering Postdoctorates, by Year of Appointment

\begin{tabular}{lccccc} 
& \multicolumn{2}{c}{$1989-1991$} & & \multicolumn{2}{c}{$1973-1991$} \\
Field of Study & $\begin{array}{c}\text { DOE } \\
\text { Postdocs }\end{array}$ & $\begin{array}{c}\text { Non-DOE } \\
\text { Postdocs }\end{array}$ & & $\begin{array}{c}\text { DOE } \\
\text { Postdocs }\end{array}$ & $\begin{array}{c}\text { Non-DOE } \\
\text { Postdocs }\end{array}$ \\
\hline Mathematics/Computer Science & $5 \%$ & $1 \%$ & & $3 \%$ & $1 \%$ \\
Life Sciences & 29 & 70 & & 27 & 66 \\
Physical Sciences & 59 & 20 & & 62 & 20 \\
Engineering & 7 & 3 & & 8 & 3 \\
Psychology/Social Sciences & 0 & 6 & & 0 & 10 \\
TOTAL & $100 \%$ & $100 \%$ & & $100 \%$ & $100 \%$
\end{tabular}


Nearly 80 percent of former DOE postdocs reported R\&D as their primary work activity, with the most recent postdocs reporting a slightly higher concentration on $R \& D$ activities. While former DOE postdocs do not differ substantially from other former postdocs in this regard, both groups report a high concentration in R\&D activities. (See Table 5.) This table also indicates that the most recent cohorts have the highest concentration in R\&D activities in 1993.

Table 5. Percent of Former Science and Engineering Postdoctorates in R\&D as Primary Work Activity in 1993

\begin{tabular}{lccccc} 
& \multicolumn{2}{c}{$1989-1991$} & & \multicolumn{2}{c}{$1973-1991$} \\
\cline { 2 - 3 } Primary Work Activity, 1993 & $\begin{array}{c}\text { DOE } \\
\text { Postdocs }\end{array}$ & $\begin{array}{c}\text { Non-DOE } \\
\text { Postdocs }\end{array}$ & & $\begin{array}{c}\text { DOE } \\
\text { Postdocs }\end{array}$ & $\begin{array}{c}\text { Non-DOE } \\
\text { Postdocs }\end{array}$ \\
\hline R\&D & $87 \%$ & $86 \%$ & & $78 \%$ & $78 \%$ \\
All other work activities & 13 & 14 & & 22 & 22 \\
TOTAL & $100 \%$ & $100 \%$ & & $100 \%$ & $100 \%$
\end{tabular}

Almost one-half of the former DOE postdocs were engaged in work in 1993 that was supported by the U.S. Department of Energy. The proportion supported by DOE funds declines with years since the postdoc was reported. However, DOE postdocs are more than 10 times as likely as non-DOE postdocs to be engaged in work supported by DOE funds. (See Table 6.)

Table 6. Percent of Former Science and Engineering Postdoctorates Supported by DOE Funds in 1993

\begin{tabular}{lccccc} 
& \multicolumn{2}{c}{$1989-1991$} & & \multicolumn{2}{c}{$1973-1991$} \\
\cline { 2 - 3 } & $\begin{array}{c}\text { DOE } \\
\text { Postdocs }\end{array}$ & $\begin{array}{c}\text { Non-DOE } \\
\text { Postdocs }\end{array}$ & & $\begin{array}{c}\text { DOE } \\
\text { Postdocs }\end{array}$ & $\begin{array}{c}\text { Non-DOE } \\
\text { Postdocs }\end{array}$ \\
\hline $\begin{array}{l}\text { Supported by DOE } \\
\text { funds in 1993 }\end{array}$ & $52 \%$ & $4 \%$ & & $41 \%$ & $2 \%$ \\
$\begin{array}{l}\text { All other } \\
\text { TOTAL }\end{array}$ & 48 & 96 & & 59 & 98 \\
TOTAL & $100 \%$ & $100 \%$ & & $100 \%$ & $100 \%$
\end{tabular}


Table 7 shows the types of employers where former postdocs worked in 1993. The former DOE postdocs were about as likely as other postdocs to be employed at 4-year colleges and universities, but much more likely to be employed at DOE M\&O contractor facilities, and at university research institutes.

Table 7. 1993 Employer of Former Science and Engineering Postdoctorates, by Year of Appointment

\begin{tabular}{|c|c|c|c|c|}
\hline \multirow[b]{2}{*}{ Type of Employer } & \multicolumn{2}{|c|}{$1989-1991$} & \multicolumn{2}{|c|}{$1973-1991$} \\
\hline & $\begin{array}{c}\text { DOE } \\
\text { Postdocs }\end{array}$ & $\begin{array}{l}\text { Non-DOE } \\
\text { Postdocs } \\
\end{array}$ & $\begin{array}{c}\text { DOE } \\
\text { Postdocs }\end{array}$ & $\begin{array}{l}\text { Non-DOE } \\
\text { Postdocs } \\
\end{array}$ \\
\hline DOE M\&O Contractor* & $18 \%$ & $0 \%$ & $16 \%$ & $1 \%$ \\
\hline Educational Institutions & & & & \\
\hline K-12 Schools & 0 & 0 & 0 & 0 \\
\hline 2-Year Colleges & 0 & 0 & 2 & 1 \\
\hline 4-Year Colleges/Universities & 30 & 28 & 27 & 30 \\
\hline Medical, Other Schools & 4 & 30 & 8 & 25 \\
\hline University Research Institutions & 19 & 7 & 13 & 5 \\
\hline Private for-Profit Firms** & 6 & 17 & 19 & 23 \\
\hline Private Not-for-Profit Firms & 16 & 7 & 9 & 6 \\
\hline State \& Local Government & 2 & 1 & 2 & 1 \\
\hline U.S. Government & 5 & 10 & 4 & 8 \\
\hline TOTAL & $100 \%$ & $100 \%$ & $100 \%$ & $100 \%$ \\
\hline
\end{tabular}

* This is a close approximation of DOE's M\&O contractor employment, but because of data limitations, it is not an exact match.

- Includes self-employed.

Table 8 shows that 46 percent of the former DOE postdocs were engaged in energy-related activities in 1993. There are many scientists and engineers who are engaged in energy-related activities without being funded by DOE, for example many of those employed in the petroleum and electric utility industries. However, this report is restricted to doctorates, and more specifically former postdocs. Among this group there were very few who were engaged in energy-related activities that were not DOE funded in 1993. Thus, the percent engaged in energy-related activities shown in Table 8 is not much higher than the percent who are DOEfunded shown earlier in Table 6.

Among those with energy-related work in 1993, half, i.e., 23 percent of the total, indicated that their work was not related to any of the applied areas of focus listed in the table. These are predominately basic researchers who can not or choose not to relate their work to applied areas 
Table 8. 1993 Work Activities of Former Science and

Engineering Postdoctorates

\begin{tabular}{lccccc} 
& \multicolumn{2}{c}{$1989-1991$} & & \multicolumn{2}{c}{$1973-1991$} \\
\cline { 2 - 3 } & $\begin{array}{c}\text { DOE } \\
\text { Postdocs }\end{array}$ & $\begin{array}{c}\text { Non-DOE } \\
\text { Postdocs }\end{array}$ & & $\begin{array}{c}\text { DOE } \\
\text { Postdocs }\end{array}$ & $\begin{array}{c}\text { Non-DOE } \\
\text { Postdocs }\end{array}$ \\
\hline Energy/Fuel & $9 \%$ & $1 \%$ & & $12 \%$ & $2 \%$ \\
Environment & 4 & 0 & & 6 & 1 \\
Health/Safety & 11 & 0 & & 4 & 0 \\
National Defense & 0 & 0 & & 1 & 0 \\
DOE-Funded/None of Above & 33 & 1 & & 23 & 1 \\
Total Energy-Related & 57 & 2 & & 46 & 4 \\
Total Not Energy-Related & 43 & 98 & & 54 & 96 \\
TOTAL & $100 \%$ & $100 \%$ & & $100 \%$ & $100 \%$
\end{tabular}

such as energy, environment, etc. They are energy-related because they are engaged in DOEfunded research. Among the rest of the energy-related, energy/fuel was the most frequently cited area of application, followed by environment and health/safety. Very few of the former postdocs reported that their work was related to national defense.

Table 8 indicates that 54 percent of the former DOE postdocs are not engaged in energyrelated work in 1993. Nearly all of these indicated they were engaged in basic research in 1993. It is not necessarily unrelated to their postdoctoral research, but it is supported by funding other than DOE funding in 1993.

All of the comments above are based on the data describing the group of postdocs shown in Table 8 in the right columns. The columns on the left of Table 8 show similar data for the most recent cohort. The proportion in the most recent cohort who are engaged in energy-related work in 1993 is somewhat higher than is the total, and among those with an applied focus, the emphasis is more on health/safety issues than on energy/fuel issues.

\section{Graduates From Top-Rated Programs}

Figure 1 reports on an indicator of the quality of the doctorate programs that produced the DOE postdocs. In 1995, the National Research Council published a report, Research Doctorate Programs in the United States: Continuity and Change, that provided several measures of the quality of graduate programs. The measure that is most widely used is a rating of the scholarly quality of the faculty in virtually all doctorate programs in the United States within 41 different fields, 31 of which are science or engineering fields. However, no assessment was attempted for a number of small fields, e.g., nuclear engineering. 
Figure 1. Percent of Former Physical Science Postdoctorates

Graduating from Top-Rated Programs

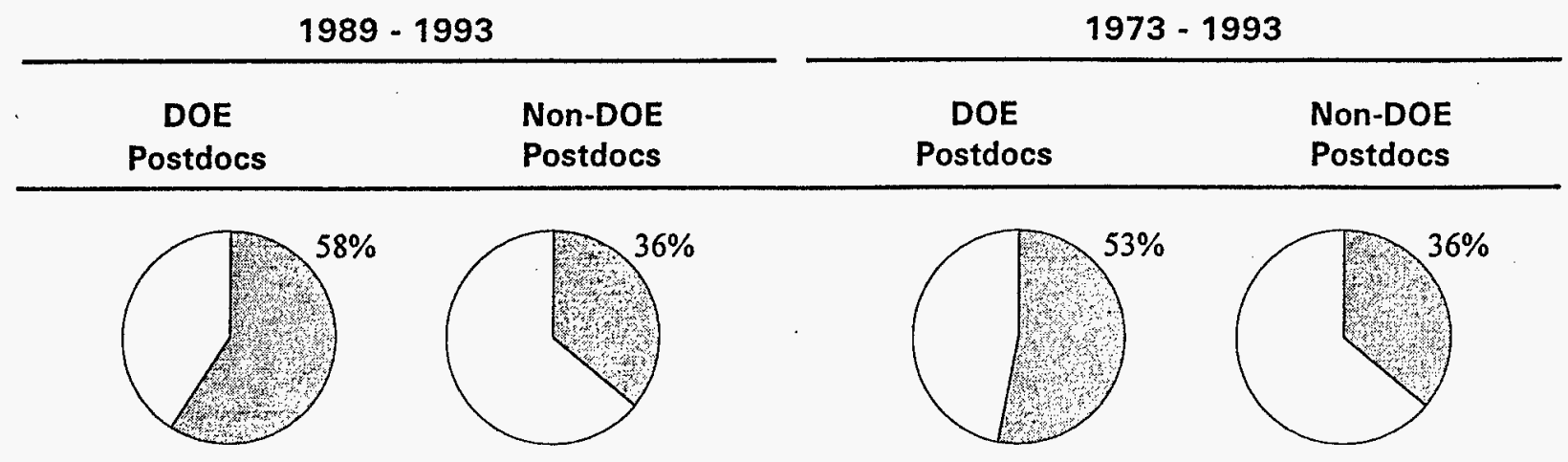

Notes: Shaded areas represent top-rated programs.

Top-rated programs are defined as those receiving an average rating of 3.95 or higher in the National Research Council's 1995 report, Research Doctorate Programs in the United States: Continuity and Change.

Figure 1 focuses on the ranking of physical science doctorate programs because the fields covered by the Research Council study include more than 97 percent of all doctorate physical scientists in 1993. Figure 1 reports the percent of former postdocs who graduated from top-rated programs. As used here, "top-rated" means that the doctorate program's faculty had a rating of 3.95 or higher on a scale of 0 to 5 . The ratings were obtained during a survey of nearly 8,000 faculty who were told that a rating of 4.01 or higher should be used to indicate a "distinguished" faculty. Thus, the top-rated doctorates in Figure 1 are from programs that were reviewed in 1993 and whose faculty were judged by their peers to be distinguished or very close to the line between distinguished and the next lower category.

It is significant that more than half of the former DOE postdocs in physical sciences did their doctorate work at top-rated programs. This is higher than the proportion of all postdocs coming from such programs. Also, the doctorates reporting DOE-funded postdocs during the most recent period, 1989-1993, are somewhat more likely than the older postdocs to come from these top-rated programs. While no single indicator provides an adequate measure of quality, this does provide rather strong evidence that the DOE research efforts that utilize postdocs have been able to compete effectively for graduates from the nation's most highly regarded graduate programs in the physical sciences.

Unfortunately, conclusions of a similar nature cannot be made about the DOE postdocs in other degree fields. Many of the doctorates in engineering and the life sciences received their degrees from programs that were not rated by the National Research Council study. 


\section{REFERENCES}

National Research Council, Research-Doctorate Programs in the United States: Continuity and Change, (Washington, D.C.: National Academy Press, 1995).

National Science Foundation, Science and Engineering Doctorates: 1960-91, NSF 93-301, Detailed Statistical Tables, (Washington, D.C., 1993).

\section{ENDNOTES}

1. The Survey of Doctorate Recipients excludes persons whose doctorate was awarded by a university outside the United States, and graduates of U.S. universities who resided outside the United States in 1993. We might also get an undercount for other reasons, for example, if a person on a DOE-funded postdoc did not report that their work was supported by the Department of Energy (or in earlier years AEC or ERDA) or failed to indicate their employment was a postdoctoral appointment. Instructions to the SDR survey define a postdoctoral appointment as "a temporary appointment in academia, industry, or government primarily provided for continued education or training in research."

2. Persons with doctorates awarded by foreign universities are excluded from this study because of data limitations. Since most are foreign-born, this exclusion tends to reduce the proportion of foreign-born among DOE-postdocs. Also, some former DOE postdocs have left the United States since completing their postdoctoral appointment. This too tends to reduce the proportion of foreign-born shown in this report, as it is restricted to persons employed in the United States in 1993. 
M97054486

|||||||||||||||||||||||||||||||||||||||.

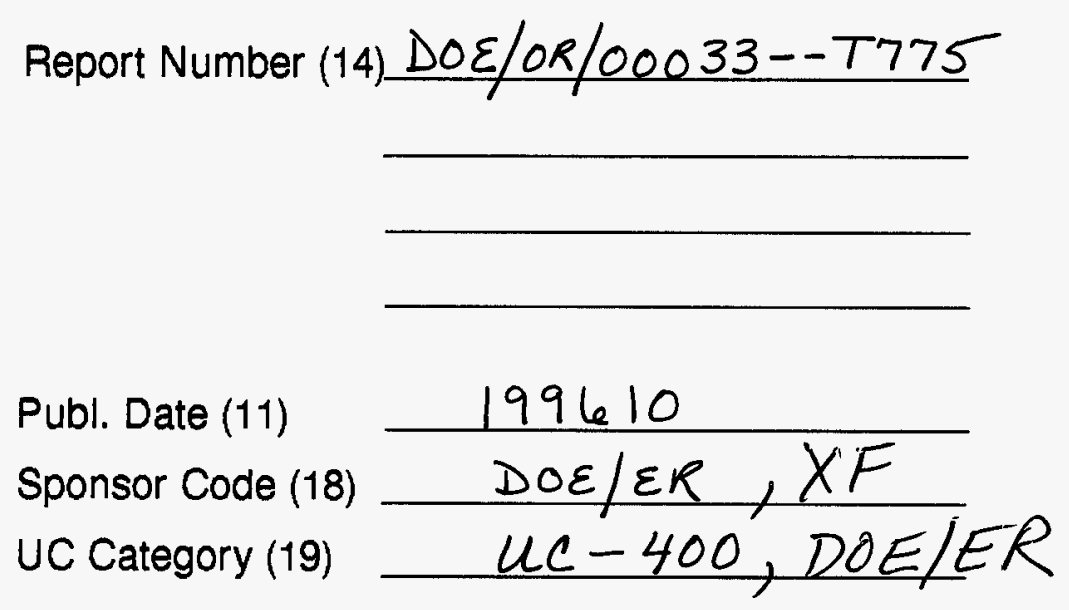

DOE 